\title{
The American Recovery and Reinvestment Act of 2009: A Review of Stimulus Spending in New York and New Jersey
}

\author{
James Orr and John Sporn
}

\begin{abstract}
The ARRA stimulus package was designed to spur economic and employment growth in response to a deepening U.S. recession and the weakened fiscal conditions of many state governments. An analysis of the local allocation of ARRA funds shows that the $\$ 35$ billion of stimulus spending in New York was relatively concentrated in expanded funding for Medicaid, while a large share of the $\$ 12$ billion allocated to New Jersey went to extending unemployment insurance benefits. While ARRA funding supplemented tax revenues in both states in fiscal years 2010 and 2011, the program's spending components are winding down, and New York and New Jersey can no longer rely on these federal transfers when preparing their budgets.
\end{abstract}

T he American Recovery and Reinvestment Act (ARRA), also known as the economic stimulus package, was signed into law on February 19, 2009. The Act had as its backdrop the deepening national recession that began in December 2007 and concern about sharply rising actual and projected budget gaps facing many state governments. The stimulus package is large - the total budgetary cost is expected to reach about $\$ 840$ billion, comprising roughly $\$ 540$ billion in spending increases and $\$ 300$ billion in tax cuts through $2019 .{ }^{1}$ ARRA's spending and tax provisions are intended to spur economic and employment growth and designed to be implemented quickly. Indeed, more than 90 percent of the program's budgetary impact was realized by the end of December 2011.

The number of spending categories in ARRA is vast, with the bulk of the package consisting of sizable federal transfers to state governments to support social services, provide assistance to unemployed and disadvantaged individuals, and fund infrastructure investments. ${ }^{2}$ Within each spending category, the distribution of funds across states largely follows formulas that govern existing federal transfers to state governments. ${ }^{3}$ Spending on some programs, however, particularly the federal funding of expanded unemployment insurance (UI) benefits, was more closely related to the

\footnotetext{
${ }^{1}$ This cost is the program's direct budgetary cost to the federal government, calculated as the sum of spending increases and tax revenue forgone, over the ten-year period from 2009 to 2019. There is some variability in the spending and tax cut projections. See http://www.recovery.gov/Transparency/ fundingoverview/Pages/fundingbreakdown.aspx and Congressional Budget Office (2012).

${ }^{2}$ An overview of the economic stimulus measures in ARRA is available at the U.S. Treasury Department's website, http://www.recovery.gov.

${ }^{3} \mathrm{~A}$ portion of the funds is allocated to projects on a competitive basis, rather than by formula. Details of the many individual categories of ARRA spending can be found at http://www.recovery.ny.gov/DirectAid/ aidnewyork.htm.
} 
extent of the downturn in a state's economy than was spending on a number of other programs. The tax cuts took a variety of forms, although they were focused largely on income tax reductions for lower- and moderate-income workers. ${ }^{4}$

In this edition of Second District Highlights, we analyze the allocation of the ARRA spending components to New York and New Jersey. We compare the magnitude of the stimulus spending in the two states and examine the differences in spending shares across major functional categories. Because most of the stimulus spending reflected federal transfers to state governments, we also discuss how ARRA funds contributed to state tax revenues in New York and New Jersey. We find that while the broad range of spending categories was similar in each state-including funding for health, education, housing assistance, and infrastructure investment - the emphasis in allocation differed considerably. In New York State, the spending allocation was concentrated in expanded funding for Medicaid. This reflected both the increase in the federal government's share of the cost of the program and the large role for Medicaid spending in the state's budget. In New Jersey, a sizable share of the stimulus was used to fund an extension of UI benefits, with the amount of federal funding linked to the steep unemployment rate among insured workers and the high weekly benefit levels. Although we do not estimate the overall effects of the American Recovery and Reinvestment Act on the two states, the stimulus spending augmented state revenues by significant amounts in 2010 and 2011.

\section{The Economies of New York and New Jersey} on the Eve of ARRA

By early 2009, a downturn was well under way in New York and New Jersey. According to measures of economic activity, the downturn began in April 2008 in New York and in January 2008 in New Jersey. ${ }^{5}$ The labor markets in both states had weakened considerably. Employment in New Jersey was down about 5 percent, matching the nationwide decline; in New York, jobs had fallen about 3 percent. Unemployment rates had increased sharply. New York's rate rose from 4.3 percent in February 2007 to 7.5 percent in February 2009; in New Jersey, the rate climbed from 4.2 percent to 8.0 percent over the same period.

The downturn was also creating significant fiscal stress for many other state governments. At the aggregate level, state and local government tax revenues had begun to decline during fiscal year 2008 (which for most states began on July 1,2007). In 2009, aggregate state and local tax revenues were down more than 5 percent compared with a year earlier - an unusually large decline even during cyclical down-

\footnotetext{
${ }^{4}$ There were also tax incentives for activities such as efficient energy use and home purchases. For more on the tax reductions and spending items in ARRA, see Congressional Budget Office (2009).

${ }^{5}$ The timing is based on movements in the Indexes of Coincident Economic Indicators for each state; the indexes, constructed by the Federal Reserve Bank of New York, are available at http://www.newyorkfed.org/research/regional _economy/coincident_summary.html.
}

Chart 1

\section{State and Local Governments' Current Tax Revenues}

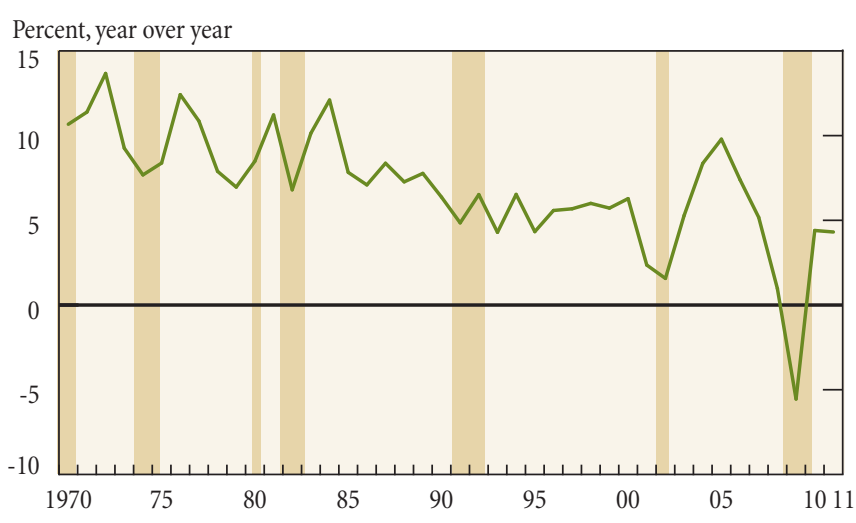

Source: U.S. Bureau of Economic Analysis.

Note: Bands indicate U.S. recessions as defined by the National Bureau of Economic Research.

turns (Chart 1). Moreover, sizable budget gaps were projected for most states for fiscal year $2010{ }^{6}$ This fiscal stress was also taking its toll in the region. For fiscal year 2010, New York faced a projected gap of roughly $\$ 13$ billion, or 24 percent of the general fund budget, while the projected gap in New Jersey was $\$ 5$ billion, or 16 percent of the state's general fund budget. One factor underlying the increases in projected budget gaps in New York and New Jersey, and indeed in much of the nation, was the weakening of state economies. The decline in activity resulted in reduced tax revenues, especially income tax revenues, and in increased demand for health and social services. ${ }^{7}$

The federal government typically provides support for state budgets in the form of intergovernmental transfers. The transfers are funded through federal tax revenues and are used to support various state activities as part of the federal government's broad role in macroeconomic management and income redistribution. ${ }^{8}$ In fiscal year 2007, the federal government distributed roughly $\$ 440$ billion to the states (Table 1), a figure representing about 28 percent of aggregate state operating revenue. ${ }^{9}$ The largest of these distributions reflected transfers from the Department of Health and Human Services, which includes funding for Medicare, Medicaid, and the Temporary Assistance for Needy Families program. Other large spending categories included transfers to states from the Department of Transportation for construction and repair of interstate highways, from the Department

\footnotetext{
${ }^{6}$ See National Conference of State Legislatures (2009).

${ }^{7}$ Deitz, Haughwout, and Steindel (2010) describe the sources of weakness in the New York and New Jersey state government budgets in the recent recession, emphasizing the vulnerability of state revenues to an economic downturn.

${ }^{8}$ Federal funding for these activities also recognizes the fact that many of them have spillover benefits to adjacent states. See Oates (1999) and Inman (2010).

${ }^{9}$ This figure includes federal aid directly to local governments in a state. See "Federal Aid to States for Fiscal Year 2007," available at http://www.census .gov/prod/2008pubs/fas-07.pdf.
} 
Table 1

\section{Federal Aid to States for Fiscal Year 2007}

\begin{tabular}{lcc} 
Department & Billions of Dollars & Percentage of Total \\
\hline Health and Human Services & 252 & 57 \\
Transportation & 48 & 11 \\
Housing and Urban Development & 48 & 11 \\
Education & 35 & 8 \\
Other agencies & 31 & 7 \\
Agriculture & 26 & 6 \\
$\quad$ Total & 440 & 100 \\
\hline
\end{tabular}

Source: U.S. Census Bureau, http://www.census.gov/pub/2008 pubs/xxx07.pdf.

of Housing and Urban Development for various forms of public housing assistance for individuals, from the Department of Education for funding of Title 1 (low-income) schools and special education programs, and from the Department of Agriculture for nutritional assistance programs. Department of Labor funding was relatively small, because state UI funds cover the cost of the state share of these benefits. These federal transfer programs represent a structure of federal funding that would underlie many of the components of the ARRA stimulus package.

\section{The Allocation of Stimulus Spending}

\section{Aggregate Stimulus Spending}

ARRA was adopted in this environment of weakening state economies and growing fiscal stress. It had the dual objectives of addressing both problems-quickly. The program was also exceptionally large. To put ARRA spending in context, we note that federal aid to state and local governments spiked by $\$ 100$ billion to $\$ 125$ billion annually between 2009 and 2011 (Chart 2). Even if we allow for a trend increase, this period is associated with a relatively sharp rise in the level of federal aid before it returned to its pre-ARRA trend. The amount of fiscal stimulus was also substantial. Using a common measure of discretionary fiscal stimulus - the cyclically adjusted federal budget balance as a share of potential GDP - we see that the aggregate federal stimulus in 2009, as measured by the year-to-year change in the share, was larger than any federal stimulus in the past four decades (Chart 3).

Nationally, ARRA's stimulus components totaled roughly $\$ 540$ billion, or about 4.0 percent of GDP in 2007. ${ }^{10}$ New York received funding of approximately $\$ 35$ billion, or roughly 3.2 percent of its gross state product in 2007; New Jersey was allocated about $\$ 12$ billion, or roughly 2.6 percent of its gross state product that year.

\footnotetext{
${ }^{10}$ The original spending estimate was $\$ 425$ billion, reported in early 2009 by the Center for American Progress (2009). As economic and fiscal conditions worsened, spending in several components of the stimulus package increased, and the aggregate spending level is currently estimated at $\$ 540$ billion to $\$ 560$ billion.
}

\section{Federal Grants in Aid to State and Local Governments}

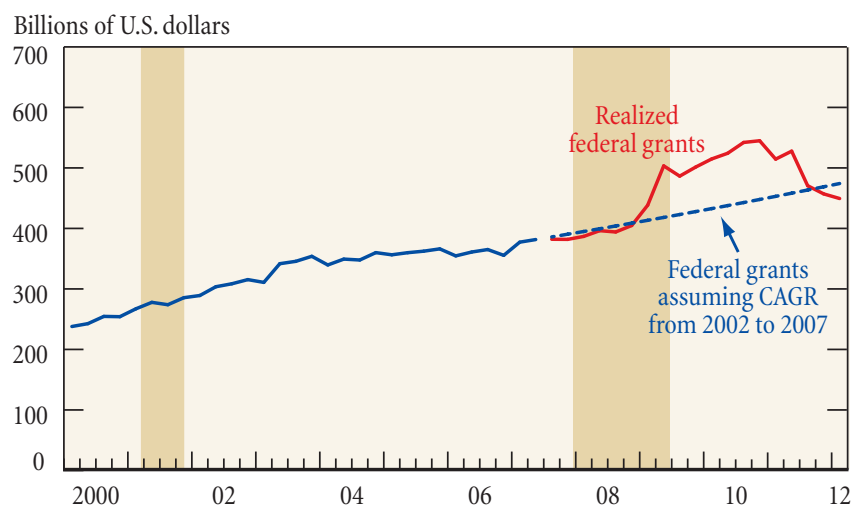

Sources: U.S. Bureau of Economic Analysis; authors' calculations.

Notes: CAGR is compound annual growth rate. Bands indicate U.S. recessions as defined by the National Bureau of Economic Research.

\section{Chart 3 \\ Cyclically Adjusted Federal Budget Surplus/Deficit as a Share of Potential GDP}

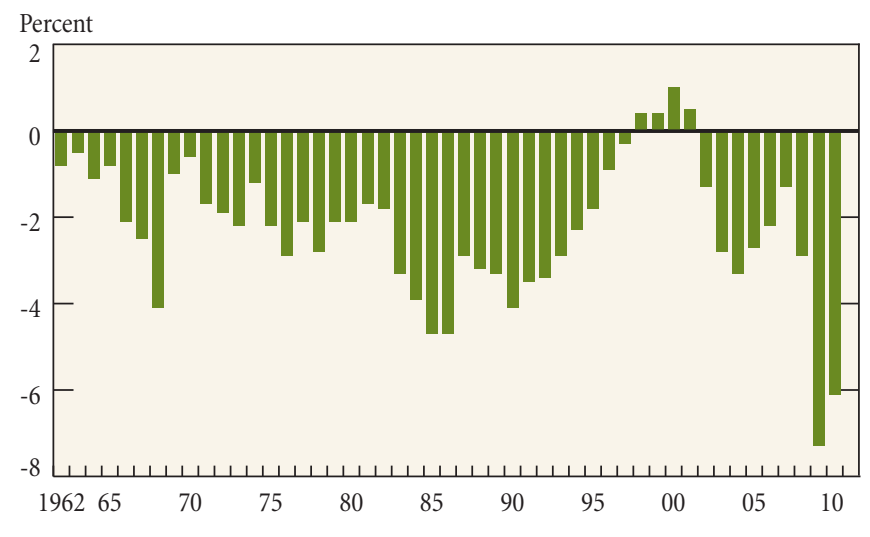

Source: Congressional Budget Office.

Aggregate stimulus spending averaged about $\$ 1,500$ per capita nationwide. Comparable figures were \$1,614 in New York and $\$ 1,377$ in New Jersey. Across states, per capita stimulus spending exhibited only little positive association with unemployment rates (Chart 4). A strong association should not necessarily be expected, because relative unemployment rates are only one of many factors that affect the allocation of stimulus spending. ${ }^{11}$ New York and New Jersey, however, had somewhat higher per capita spending levels than did states with similar unemployment rates, although overall spending allocated to the two states does not appear disproportionate.

\footnotetext{
11 Wilson (2009) shows a positive relationship between state stimulus spending allocations and projected state budget gaps when the stimulus package was introduced.
} 
Chart 4

\section{Total Spending per Capita and Unemployment Rate by State}

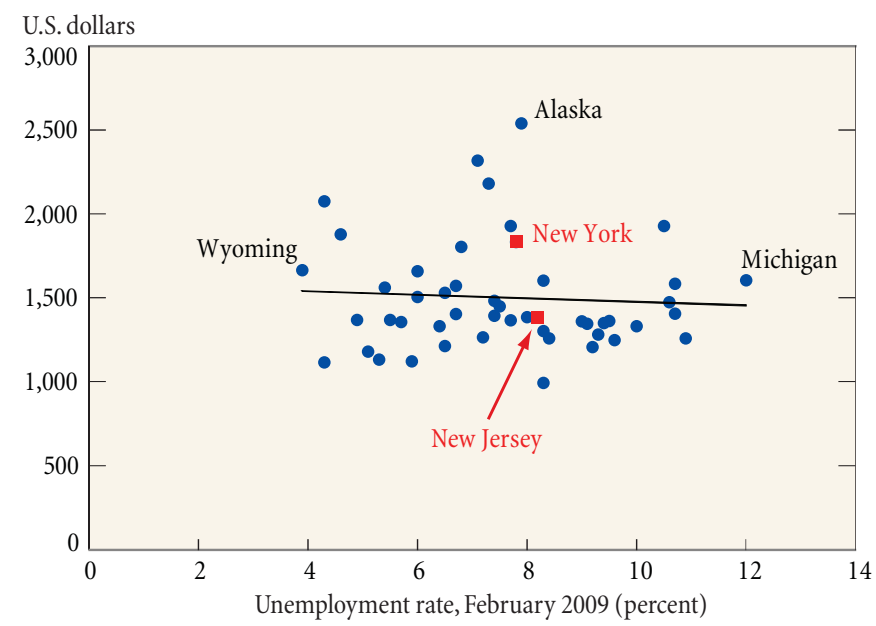

Sources: Recovery.gov; authors' calculations.

\section{Major Categories of Stimulus Spending}

The ARRA stimulus spending was implemented in several steps. First, funds were allocated to federal agencies with the purpose of supporting specific programs. Second, each agency authorized spending on various programs in each state, with the distribution of funds across states determined largely by program-specific formulas. Third, allocated funds were authorized to be spent on individual programs, and payment was closely tracked. Up-todate information on the amount of funds allocated and deployed by each agency, as well as the individual categories of spending within each agency, both nationally and by state, is reported on the Treasury Department's website. ${ }^{12}$

Together, the Departments of Health and Human Services, Education, and Labor accounted for half of the stimulus spending nationally by federal agencies (Table 2). Within Health and Human Services, the largest single category of spending was for Medicaid, with the program accounting for about a third of funds distributed. Although Medicaid is administered at the state level, the federal government shares financing with the states; ARRA essentially increased the federal share of financing already provided. The remaining funds were used for many services, such as expanded programs for children and investments in health information technology. One feature of the increased Medicaid funding was the ability to give states some flexibility to direct to other state government services revenues that would have gone to financing Medicaid; the funds in effect were a form of fiscal relief for states.

\footnotetext{
12 Estimates of the jobs created as a result of the stimulus spending are also reported. However, these estimates are limited to a count of newly created jobs on ARRA-funded projects, and not those in which the stimulus funds supported ongoing activities and effectively avoided layoffs.
}

Spending by the Education Department was designed largely to help maintain the level of various educational services. Funding was directed to programs such as Head Start and IDEA (Individuals with Disabilities Education Act) as well as to Pell Grants and Title 1 schools. Notably, Education Department spending included funding of a newly established program in ARRA known as the State Fiscal Stabilization Fund (SFSF). The fund received an appropriation of roughly $\$ 50$ billion aimed at minimizing or avoiding any disruptions in the provision of educational services. The allocated funds could be used to pay salaries or avoid layoffs of educational personnel. ${ }^{13}$ Like the expanded Medicaid funding, the financial support for education provided by the SFSF was a form of fiscal relief in the sense that state funds that otherwise would have supported educational activities could be directed toward other state services.

The majority of Labor Department spending was used to fund additional weeks of UI benefits beyond the regular twenty-six weeks available for eligible unemployed workers in most states. Two programs provided for federal funding of these benefit extensions. One extended benefits for unemployed workers under a federal law dating back to 1970 that has provided for additional weeks of benefits in periods of high and rising unemployment. A second extended benefits under the 2008 Emergency Unemployment Compensation program, which recognized that unemployment and unemployment duration were rising and state UI funds were being depleted. Federal funding for these programs was rolled into ARRA, and reached about $\$ 30$ billion, or roughly half of Labor Department spending. States that agreed to expand UI eligibility criteria and provide job training for unemployed workers under the federal Workforce Investment Act received additional funding.

Other programs receiving smaller amounts of support included the Department of Transportation, which used the funds for maintenance and repair of interstate highways as well as for mass transit, rail, and air facilities; the Department of Housing and Urban Development, which provided support to individuals through expanded public housing and neighborhood services; and the Department of Energy, which supported weatherization and energy-efficiency investments. One feature of the funding provided to states through these agencies is the expectation of "maintenance of effort" by the state; that is, funds were to be used to support activities that otherwise would not have been undertaken. This feature reflected an effort to avoid the substitution of federal funds for state funds and to help support a net increase in activity.

\section{Stimulus Spending in New York and New Jersey}

Spending in New York, when compared with the nation, was more concentrated in the Department of Health and Human Services and was directed largely at expanded Medicaid spending.

\footnotetext{
${ }^{13}$ Stimulus spending to support education in New Jersey is discussed in Chakrabarti
} and Sutherland (2012) and in New York in Chakrabarti and Setren (2011). 


\section{Major Spending Categories of the American Recovery and Reinvestment Act}

\begin{tabular}{|c|c|c|c|c|c|c|}
\hline \multirow[b]{2}{*}{ Category } & \multicolumn{2}{|c|}{ New York } & \multicolumn{2}{|c|}{ New Jersey } & \multicolumn{2}{|c|}{ Nation } \\
\hline & $\begin{array}{c}\text { Billions } \\
\text { of Dollars }\end{array}$ & $\begin{array}{c}\text { Percentage } \\
\text { of Total }\end{array}$ & $\begin{array}{c}\text { Billions } \\
\text { of Dollars }\end{array}$ & $\begin{array}{l}\text { Percentage } \\
\text { of Total }\end{array}$ & Billions of Dollars & $\begin{array}{c}\text { Percentage } \\
\text { of Total }^{\mathrm{a}}\end{array}$ \\
\hline Department of Health and Human Services & 13.8 & 39 & 2.8 & 24 & 119.6 & 21 \\
\hline Department of Education & 7.1 & 20 & 2.3 & 19 & 97.3 & 17 \\
\hline Department of Labor & 4.7 & 13 & 3.5 & 30 & 67.5 & 12 \\
\hline Department of Housing and Urban Development & 1.3 & 4 & 0.4 & 3 & 13.5 & 2 \\
\hline Department of Transportation & 3.2 & 9 & 1.2 & 10 & 47.6 & 8 \\
\hline Other & 5.3 & 15 & 1.7 & 14 & 215.4 & 38 \\
\hline Total & 35.4 & 100 & 11.9 & 100 & 560.9 & 100 \\
\hline
\end{tabular}

Sources: Recovery.gov, http://www.recovery.gov/Transparency/RecipientReportedData/Pages/AgencyTotalsByState.aspx; authors' calculations.

${ }^{a}$ Column does not sum to 100 because of rounding.

Chart 5

\section{Department of Health and Human Services Medicaid Assistance and 2007 Expenditures per Capita}

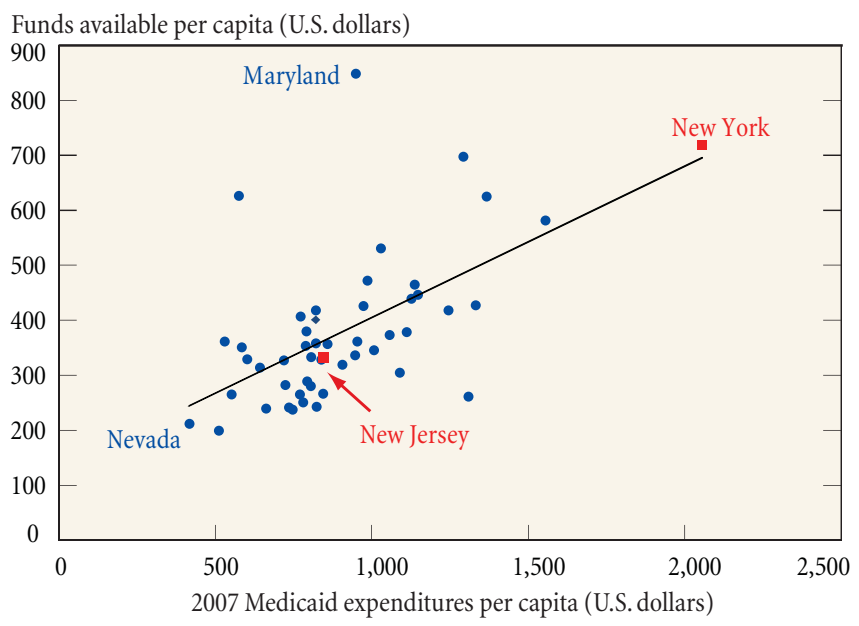

Sources: Recovery.gov; authors' calculations.

\section{Chart 6}

\section{Department of Labor (UI Benefits) and Unemployment Rate by State}

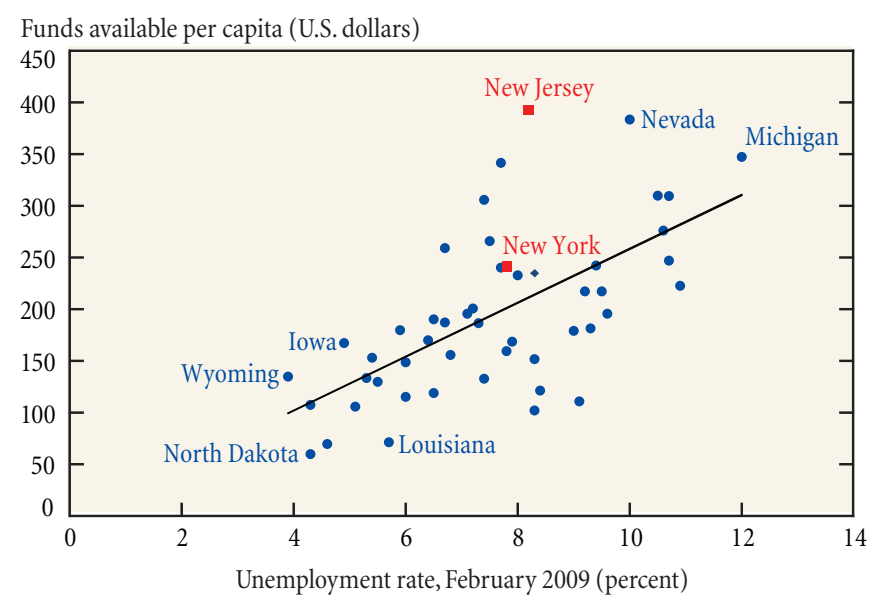

Sources: Recovery.gov; authors' calculations.

Notes: UI is unemployment insurance. $y=26.052 x-2.1759 ; R^{2}=0.4056$.
Underlying the large federal allocation to New York for Medicaid is the state's federal medical assistance percentage (FMAP), the rate at which states are reimbursed for Medicaid expenses, together with the relatively broad coverage and wide participation in the state's Medicaid program (Box 1, p. 6). Chart 5 displays the amount of Medicaid assistance per capita provided by ARRA to each of the fifty states and the District of Columbia as well as the 2007 level of Medicaid expenditures per capita. We observe a positive relationship between the level of per capita Medicaid expenditures prior to ARRA's introduction and funds provided by ARRA; New York's high level stands out.
In New Jersey, the largest spending category was funding through the Labor Department. The state received funds for additional weeks of UI benefits and for support of expanded eligibility for benefits. This spending recognized the fact that since the onset of the recession, U.S. state unemployment insurance funds had become severely strained because of a dramatic increase in claims. This was especially true in New Jersey, whose fund in 2009 was virtually depleted. While spending levels in this category not surprisingly show a strong link to unemployment rates, New Jersey is an exception (Chart 6). Underlying these sizable per capita benefits was the high unemployment rate among insured workers, the potential eligibility of certain work- 
Box 1

\section{Medicaid Spending Distribution Formula}

Although Medicaid is administered at the state level, the federal government shares the funding with states. The federal medical assistance percentages, or FMAPs, are used to calculate the dollar amount of federal contributions that states receive for expenditures incurred by Medicaid. ${ }^{a}$ FMAPs are computed on an annual basis for each state using the state's three-year average income per capita and the nation's three-year average income per capita. The specific formula is:

\section{State FMAP $=1-(($ per capita income of the state $) \wedge 2 /($ per capita income of the U.S. $) \wedge 2 \times 0.45)$.}

Because FMAPs are calculated on an annual basis, in any given year the federal contribution might be less than that of the previous year. The American Recovery and Reinvestment Act (ARRA) temporarily increased the percentage contributions by the federal government for all states using three measures:

- All states were protected from a decrease in the FMAP because of a "hold-harmless" provision effective October 1, 2008, through December 31,2010. For fiscal year 2009, all states received the higher FMAP rate for either fiscal year 2008 or fiscal year 2009. For fiscal year 2010, the same methodology was used and the highest FMAP of fiscal years 2008-10 was chosen.

- The federal contribution rate was increased 6.2 percentage points above the hold-harmless rate.
- The federal contribution was increased further for states with high unemployment rates. Specifically, for the first quarter and second quarter of fiscal year 2010, the unemployment adjustment was based on the difference between the three-month average unemployment rate ending December 2009 and the lowest three-month average unemployment rate since January 2006. The magnitude of this difference determined the size of the unemployment rate adjustment. The calculation of the increased federal contribution first computed the factor ( 96.9 minus hold-harmless rate). If a state's unemployment difference was between 1.5 and 2.5 percent, the factor was multiplied by 5.5 percent and added to the federal contribution rate; between 2.5 and 3.5 percent, the state qualified for an 8.5 percent increase; if the difference exceeded 3.5 percent, the state qualified for an 11.5 percent increase. As a result, the final value for the federal FMAP contribution was:

Hold-harmless rate +6.2 percent + the unemployment adjustment.

New York and New Jersey started with a hold-harmless FMAP rate of 50 percent (see table). The across-the-board 6.2 percentage points was then added, raising the FMAP in the states to 56.2 percent. The unemployment rate difference was 4.6 for New York and 5.7 for New Jersey, qualifying both states for an additional FMAP contribution of 11.5 percent. Combining all of these values and placing them into the formula for increased FMAP assistance under ARRA gave New York and New Jersey FMAPs of 61.59 percent. However, since per capita Medicaid spending in New York was the highest in the nation-and more than double that of New Jersey-these increased contribution rates resulted in proportionately higher Medicaid assistance in New York.

\section{Increased FMAPs under ARRA for Q1 and Q2 of Fiscal Year (FY) 2010}

\begin{tabular}{|c|c|c|c|c|c|c|c|c|c|}
\hline State & $\begin{array}{l}\text { Regular FMAP } \\
\text { for FY } 2010\end{array}$ & $\begin{array}{l}\text { "Hold-Harmless" } \\
\text { Rate }\end{array}$ & $\begin{array}{l}\text { "Hold-Harmless" } \\
\text { Rate plus } 6.2 \\
\text { Percentage Points }\end{array}$ & $\begin{array}{l}\text { Three-Month } \\
\text { Average } \\
\text { Unemployment }\end{array}$ & $\begin{array}{l}\text { Lowest Three-Month } \\
\text { Average Unemployment } \\
\text { since January } 2006\end{array}$ & $\begin{array}{l}\text { Unemployment } \\
\text { Difference }\end{array}$ & $\begin{array}{c}\text { Unemployment } \\
\text { Tier }\end{array}$ & $\begin{array}{l}\text { Unemployment } \\
\text { Adjustment }\end{array}$ & $\begin{array}{l}\text { ARRA FMAP for } \\
\text { Q2 of FY } 2010\end{array}$ \\
\hline New York & 50.00 & 50.00 & 56.20 & 9.90 & 4.20 & 5.70 & 11.50 & 5.39 & 61.59 \\
\hline New Jersey & 50.00 & 50.00 & 56.20 & 8.90 & 4.30 & 4.60 & 11.50 & 5.39 & 61.59 \\
\hline
\end{tabular}

Source: Congressional Research Service.

Notes: FMAP is the federal medical assistance percentage; ARRA is the American Recovery and Reinvestment Act.

a For a detailed explanation of FMAPs as well as information for all states, see the Congressional Research Service report,
http://www.aging.senate.gov/crs/medicaid6.pdf.

ers for up to ninety-nine weeks of UI benefits, and the fact that New Jersey has among the highest weekly UI benefit maximums in the nation (Box 2).

\section{Stimulus Spending and State Revenues}

One of ARRA's stated goals was the stabilization of state budgets. Within the stimulus package, direct fiscal relief to states was provided primarily through two programs: Medicaid (with expanded funding) and the State Fiscal Stabilization Fund. Nationally, the programs provided a total of roughly $\$ 140$ billion for fiscal years
2009-11. The sizable amount and composition of stimulus spending from these funds in New York and New Jersey suggest that the program made a significant contribution to state revenues. ${ }^{14} \mathrm{In}$ New York, funding by these two programs totaled about $\$ 11$ billion over three fiscal years: $\$ 1.3$ billion in $2009, \$ 5.3$ billion in

\footnotetext{
${ }^{14}$ Job preservation and creation were also goals of the stimulus spending, although we do not present estimates of these effects in New York or New Jersey. Estimates of the stimulus package's effects on the national economy range widely (see, for example, Cogan and Taylor [2010] and Wilson [forthcoming]).
} 
Box 2

\section{Unemployment Insurance Funding Distribution Formula}

The 2008 Emergency Unemployment Compensation (EUC) program allocated federal funds to states through the Department of Labor to support unemployment insurance (UI) benefits for unemployed workers beyond the regular twenty-six weeks provided by most state programs. The funding for these benefit extensions was continued and expanded by appropriations in the American Recovery and Reinvestment Act (ARRA).

The benefits under the EUC were structured in four tiers: ${ }^{a}$

- Tiers 1 and 2 extended benefits for up to thirty-four weeks, and workers in all states qualified for these extensions.

- Tier 3 provided up to an additional thirteen weeks of benefits and was targeted to workers in states with an insured unemployment rate that averaged at least 4 percent over the previous thirteen weeks and an average total unemployment rate of 6 percent over the previous three months.

- Tier 4 provided up to an additional six weeks of benefits for workers in states with an insured unemployment rate averaging at least 6 percent and a total unemployment rate of at least 8.5 percent.

Extended unemployment benefits were available for workers who exhausted their EUC benefits; the program made workers eligible for up to an additional twenty weeks of benefits. For a worker to qualify for extended benefits, a state's three-month average seasonally adjusted unemployment rate must equal or exceed 110 percent of the corresponding rate in each of the past three years.

Workers were thus potentially eligible to receive up to ninety-nine weeks of unemployment benefits - twenty-six weeks of regular UI, fiftythree weeks of benefits under the EUC, and an additional twenty weeks of extended benefits.

There are no federal standards for UI benefits. The amount of ARRA funding for UI received by any state reflects the state's total unemployment rate, the insured unemployment rate, the number of workers eligible to receive UI, and the average weekly benefit amount. ${ }^{\mathbf{b}}$ Certain unemployed workers in New York and New Jersey were at times eligible to receive up to ninety-nine weeks of UI benefits. State benefits and eligibility criteria led to relatively large allocations to New Jersey, on a per capita basis, compared with New York and states with similar unemployment rates. Underlying these large allocations were the state's relatively high total and insured unemployment rates, high share of unemployed workers claiming UI, and the fact that New Jersey has one of the highest maximum weekly UI benefit amounts of any state-almost $\$ 600$, compared with less than $\$ 400$ in New York.

\footnotetext{
a The EUC program has been modified several times, and recent legislation has reduced the number of benefit weeks in each tier (see http://www.workforcesecurity.doleta.gov/unemploy/pdf/euc08.pdf). Funding for the program is scheduled to expire at the end of 2012.

b See U.S. Department of Labor, Office of Unemployment Insurance, “Unemployment Compensation: Federal-State Partnership," April 2012, available at http://www.ows.doleta.gov/unemploy/pdf/partnership.pdf.
}

2010, and $\$ 4.6$ billion in $2011 .{ }^{15}$ About three-quarters of these funds took the form of enhanced federal support for Medicaid, with the remainder allocated through the SFSF. In 2009 and 2010, these funds represented roughly 8 percent of state revenues. ARRA funds were also used, although to a much lesser extent, to support the state's budget in fiscal year 2011.

In New Jersey, state tax revenues were augmented by almost $\$ 1$ billion of ARRA funds in fiscal year 2009. Revenues in fiscal year 2010 were augmented by a larger amount, $\$ 2.3$ billion, representing about 8 percent of total revenues in that fiscal year. ${ }^{16}$

\section{Conclusion}

The American Recovery and Reinvestment Act of 2009 was a major program of discretionary federal fiscal assistance implemented largely through the states. With a vast number of spend-

\footnotetext{
${ }^{15}$ See http://www.budget.ny.gov/pubs/archive/fy1011archive/eBudget1011/ fy1011littlebook/BriefingBook.pdf.

${ }^{16}$ For a discussion of the longer-term challenges facing the state budgets of $\mathrm{New}$ York and New Jersey, see "Report of the State Budget Crisis Task Force," available at http://www.statebudgetcrisis.org/wpcms/wp-content/images/Report-of-the -State-Budget-Crisis-Task-Force-Full.pdf.
}

ing categories totaling roughly $\$ 540$ billion in relief, the program was the largest fiscal stimulus package in the past four decades. New York received approximately $\$ 35$ billion in stimulus funds and New Jersey about $\$ 12$ billion. On a per capita basis, these amounts were broadly in line with the national share.

The program used existing categories of federal transfers to states, and the amount of funds received by a state was determined to a large extent by category-specific distribution formulas. New York and New Jersey received funding across all categories, but the concentration varied. New York had an outsized allocation of funding for Medicaid, largely because the ARRA formula augmented the state's relatively high pre-ARRA spending. In comparison, New Jersey had an outsized funding of unemployment insurance. This was largely the result of a combination of New Jersey's relatively high unemployment rate, which qualified unemployed workers for the maximum number of weeks of benefits, and the state's high weekly benefit amounts.

ARRA spending supplemented revenues in both states in fiscal years 2010 and 2011. The supplemental funds were intended to help states continue their spending on a variety of services as well as maintain and expand their infrastructures. The spending 
components of the ARRA program, however, are winding down. While some infrastructure investments remain to be completed, the majority of the ARRA stimulus spending has been paid out. In New York and New Jersey, almost 90 percent of the allocated funds have been distributed as of year-end 2011; most of the funding still available will be paid out by the Departments of Education and Transportation. The two states are expecting very little Medicaid funding and no funding through the State Fiscal Stabilization Fund. Going forward, New York and New Jersey can no longer rely on these federal transfers when preparing their budgets.

\section{References}

Center for American Progress. 2009. “Interactive Map: Recovery beyond the Beltway: The Nationwide Allocation of Recovery Funding," by Will Straw. January 23 (updated February 13). Available at http://www.americanprogress. org/issues/2009/01/house_stimulus_overview.html.

Chakrabarti, Rajashri, and Elizabeth Setren. 2011. “The Impact of the Great Recession on School District Finances: Evidence from New York.” Federal Reserve Bank of New York Staff Reports, no. 534, December.

Chakrabarti, Rajashri, and Sarah Sutherland. 2012."Precarious Slopes? The Great Recession, Stimulus, and New Jersey Schools.” Federal Reserve Bank of New York Staff Reports, no. 538, January.

Cogan, John F., and John B. Taylor. 2010. "What the Government Purchases Multiplier Actually Multiplied in the 2009 Stimulus Package.” NBER Working Paper no. 16505 , October.
Congressional Budget Office. 2009. "Estimated Macroeconomic Impacts of the American Recovery and Reinvestment Act of 2009." March 2. Available at http:// www.cbo.gov/ftpdocs/100xx/doc10008/03-02-Macro_Effects_of_ARRA.pdf.

.2012."Estimated Impact of the American Recovery and Reinvestment Act on Employment and Economic Output from October 2011 through December 2011." February 12. Available at http://www.cbo.gov/sites/default/files/ cbofiles/attachments/02-22-ARRA.pdf.

Deitz, Richard, Andrew F. Haughwout, and Charles Steindel. 2010. “The Recession's Impact on the State Budgets of New York and New Jersey." Federal Reserve Bank of New York Current Issues in Economics and Finance, Second District Highlights 16, no. 6 (June-July).

Inman, Robert P. 2010. “States in Fiscal Distress.” NBER Working Paper no. 16086, June.

National Conference of State Legislatures. 2009. "Update on State Budget Gaps: FY 2009 and FY 2010." February 20. Available at http://www.ncsl.org/Portals/1/ documents/pubs/statebudgetgaps.pdf.

Oates, Wallace E. 1999. “An Essay on Fiscal Federalism." Journal of Economic Literature 37, no. 3 (September): 1120-49.

Wilson, Daniel. 2009. "Are Fiscal Stimulus Funds Going to the 'Right' States?" Federal Reserve Bank of San Francisco Economic Letter no. 2009-14, April 17.

- Forthcoming. "Fiscal Spending Jobs Multipliers: Evidence from the 2009 American Recovery and Reinvestment Act." American Economic Journal: Economic Policy. Working paper, Federal Reserve Bank of San Francisco, available at http://www.frbsf.org/publications/economics/papers/2010/wp10-17bk.pdf.

\section{ABOUT THE AUTHORS}

James Orr is an assistant vice president in the Research and Statistics Group of the Federal Reserve Bank of New York; John Sporn is a senior analyst in the Bank's Markets Group.

Current Issues in Economics and Finance is published by the Research and Statistics Group of the Federal Reserve Bank of New York. Linda Goldberg and Thomas Klitgaard are the editors.

The content co-editor of this article is Richard Peach.

Editorial Staff: Valerie LaPorte, Mike De Mott, Michelle Bailer, Karen Carter, Anna Snider

Production: Jessica lannuzzi, David Rosenberg, Jane Urry

Subscriptions to Current Issues are free. Send an e-mail to Research.Publications@ny.frb.org or write to the Publications Function, Federal Reserve Bank of New York, 33 Liberty Street, New York, N.Y. 10045-0001. Back issues of Current Issues are available at http://www.newyorkfed.org/research/current_issues/.

The views expressed in this article are those of the authors and do not necessarily reflect the position of the Federal Reserve Bank of New York or the Federal Reserve System. 


\section{Follow Us on Twitter!}

The Research Group's Twitter feed is designed to offer the first word on developments in the Group, such as:

- new publications and blog posts,

- updates on economists' work and speaking engagements,

- postings of key indexes and data,

- media coverage of the Group's work, and

- $\quad$ other news of interest to website visitors.

Follow us: @NYFedResearch

\section{RELATED READINGS FROM THE FEDERAL RESERVE BANK OF NEW YORK'S RESEARCH GROUP}

\section{Liberty Street Economics Blog Posts}

Available at http://libertystreeteconomics.newyorkfed.org/

Good News or Bad on New York City Jobs?

Jason Bram and James Orr

August 13, 2012

Is Wall Street the Only Street in New York City?

Jason Bram, Jonathan Hastings, and James Orr June 6, 2012

Tough Decisions, Depleted Revenues: New Jersey's

Education Finances during the Great Recession

Rajashri Chakrabarti and Sarah Sutherland

February 1,2012
How Did the Great Recession Affect New York State's

Public Schools?

Rajashri Chakrabarti and Elizabeth Setren

January 30, 2012

Unintended Consequences in School

Accountability Policies

Rajashri Chakrabarti and Noah Schwartz

November 28, 2011 


\section{Articles and Papers}

Report on the Competitiveness of Puerto Rico's Economy

June 29, 2012

This report, prepared by the Bank's Research, Emerging Markets and International Affairs, and Communications Groups, analyzes the challenges facing Puerto Rico and makes recommendations on how to capitalize on the Island's strengths to restore growth.

Available at http://www.newyorkfed.org/regional/puertorico/ index.html.

The Role of Colleges and Universities in Building Local Human Capital

Jaison R. Abel and Richard Deitz

Second District Highlights, vol. 17, no. 6, 2011

Colleges and universities can contribute to the economic success of a region by deepening the skills and knowledge—or human capital — of its residents. Producing graduates who join the region's educated workforce is one way these institutions increase human capital levels. In addition, the knowledge and technologies created through research activities at area universities may not only attract new firms to a region but also help existing businesses expand and innovate. These "spillover effects" can in turn raise the region's demand for high-skilled workers.

\section{The Recession's Impact on the State Budgets of New York} and New Jersey

Richard Deitz, Andrew F. Haughwout, and Charles Steindel Second District Highlights, vol. 16, no. 6, 2010

In the wake of the most recent U.S. recession, both New York State and New Jersey have faced multibillion-dollar budget gaps. An analysis of the makeup of their budgets reveals that the states' heavy reliance on personal income taxes-particularly from high-wage earners in the finance sector-has exacerbated revenue shortfalls. To close their budget gaps, New York and New Jersey have had to make difficult choices about tax increases and service cuts. In the future, the states might take steps to avert such budget quandaries by establishing "rainy day" funds or restructuring taxes to make them less sensitive to the business cycle.
Bypassing the Bust: The Stability of Upstate New York's Housing Markets during the Recession

Jaison R. Abel and Richard Deitz

Second District Highlights, vol. 16, no. 3, 2010

Over the past decade, the United States has seen real estate activity swing from boom to bust. But upstate New York has been largely insulated from this volatility, with metropolitan areas such as Buffalo, Rochester, and Syracuse even registering home price increases during the recession. An analysis of upstate housing markets over the most recent residential real estate cycle indicates that the region's relatively low incidence of nonprime mortgages and the better-than-average performance of these loans contributed to this stability.

\section{Is the Worst Over? Economic Indexes and the Course} of the Recession in New York and New Jersey

Jason Bram, James Orr, Robert Rich, Rae Rosen, and Joseph Song Second District Highlights, vol. 15, no. 5, 2009

The New York-New Jersey region entered a pronounced downturn in 2008, but the pace of decline eased considerably in spring 2009 and then leveled off in July, according to three key Federal Reserve Bank of New York economic indexes. These developments, in conjunction with a growing consensus that the national economy is headed for recovery, suggest that the worst may be over for the region's economy. However, a downsizing of the area's critical finance sector could pose a major risk to the economic outlook going forward-particularly for New York City. 
New Measures of Economic Growth and Productivity in Upstate New York

Jaison R. Abel and Richard Deitz

Second District Highlights, vol. 14, no. 9, 2008

Newly available measures of GDP at the metropolitan area level now afford a more comprehensive view of regional economic activity. An analysis of upstate New York's economic performance using these measures points to below-average output growth between 2001 and 2006 along with productivity levels and productivity growth below the U.S. average. The region's performance overall, however, is somewhat better than that of many manufacturing-oriented metro areas in the Great Lakes region.

\section{The Price of Land in the New York Metropolitan Area}

Andrew Haughwout, James Orr, and David Bedoll

Second District Highlights, vol. 14, no. 3, 2008

The price of vacant land in an urban area is a fundamental indicator of an area's attractiveness. However, because the value of vacant land is hard to measure, indirect methods are typically used to gauge prices. A more direct approach to measuring land prices, using a unique data set, reveals that the price of unimproved land in the New York area is high, and rose sharply from 1999 to 2006. The rising trend suggests the underlying strength of the area's economy and the increasing value of the area’s productivity and amenities.
Trends and Developments in the Economy of Puerto Rico Jason Bram, Francisco E. Martínez, and Charles Steindel Second District Highlights, vol. 14, no. 2, 2008

A two-year-long economic downturn and a persistent income gap with the U.S. mainland contribute to an uncertain outlook for Puerto Rico. Still, the commonwealth possesses a skilled and educated workforce, a favorable business climate, and the benefits of U.S. legal and financial structures-advantages that could encourage the development of new industries and create the potential for sustained growth. 